\title{
Deathbed, Breathing the Last, and Funeral Procession: Musing under the canopy of history
}

\author{
R.K. K. Rajarajan \\ School of Tamil, Indian Languages and Rural Arts, Gandhigram Rural University, Gandhigram - \\ 624 302. Email: rkkrajarajan@yahoo.com
}

\begin{abstract}
"In Nature's book of infinite secrecy/ A little I can read". These words of the soothsayer in Shakespeare's 'Antony and Cleopatra' (Act I, Scene ii) is symbolic. It is uttered in the company of Charmian and Iras, maidens attending on Cleopatra (Hutchinson n.d.: pl. facing p. 39); perhaps designed to foretell the end of Mark Antony ${ }^{1}$ in the near future after the battle of Actium. Everything existing on this earth must pass through nature to eternity that is denoted by the common word "death". But, death at a young age is cruel whether natural, volunteered, accidental or due to any injunction. The brilliant Tamil woman-mystic Ānțāl $\left.\right|^{2}$ and the versatile English poet, John Keats ${ }^{3}$ died at a young age that was a great loss to the world of literature. The Buddha as a novice-monk was in pursuit of death but gave up the unnatural process of suicidal mortification (Le-Bon 1974: fig. p. 55, Yiengpruksawan 2007: 44-63, Ahuja 2013: fig. 6, pp. 21-24) and resorted to yoga to realize cosmic realities under the Bodhi tree at Sāranāth (Parimoo et al. 1991: I, pls. 50-45, 106-107) ${ }^{4}$. Jesus of Nazareth (cf. Gallico 1999: figures on pages 111, 20 \& 42, Ahuja 2013: fig. 39) and Muhammad of Mecca (cf. Stewart 1980: figures on pages 36-37) died at a relatively young age; otherwise the history of world's greatest religions would have been different. If they had lived long [...]; this "if" factor in history is difficult to answer. Neither Jesus nor Muhammad "invited" nor "pursued" death (Settar 1986, 1990); one was crucified by Jewish treachery of those times and other of some other malady. Preachers of terrorism do not die under a peaceful environment. "Whoso sheddeth man's blood, by man shall his blood be shed for in the image of God made he man" (Genesis 9.6).
\end{abstract}

Keywords: Death, Tamil, bhakti, Vaiṣṇava, Periyāḷvār, Āṇṭāl, tirumoḷi

Death or the process of death is not the main concern of this brief communication. ${ }^{5}$ Death and mummies have a long story to tell from the Egyptian pyramids (Hutchinson n.d.: 20, 39) to the mahāstūpa of Borobudūr (Ariswara 2008: 2 fig) in Indonesia, including the several hundreds of ruined funerary from Gandhāra in the northwest of South Asia to Sañchī in central India and Amarāvatī in peninsular India; new reports of such dilapidated monuments and other artifacts coming to light from time to time (Shah 2011: 111-30, cf. Verardi 2012: 153-72 and Ahuja 2013: 21-23, fig. 5).

The present article is a summary of ten hymns, the work of the Tamil Vaiṣnava mystic Periyālvār, author of the most melodious among the bhakti hymns ${ }^{6}$ bearing on the devotional cult that swept over the Tamil country from the $5^{\text {th }}$ (e.g. the Tamil work Paripattal, cf. Zvelebil 1974: 49) to the $9^{\text {th }}$ century CE. Quite unusually, deviating from the central theme of the story, i.e. bhakti "devotion" Periyālvār (Fig. 2) talks of the agony of death7 (Tirumoli 4.5.1-10), which it is not clear, has anything to do with the death or apotheosis of Ântāl (Fig. 3). Of course, the death-motif is artificially linked with devotion to Vișnu in a bizarre locale. ${ }^{8}$ The cited tirumoli ("sacred saying") may be interesting from the anthropologist's point of view that may be examined by trained scholars for further investigation. I am just summarizing the thoughts in an orderly pattern keeping track of the contemporary death-bed conventional treatment and ceremonies. Śräddha again is an extensive field

(c) AesthetixMS 2019. This Open Access article is published under a Creative Commons Attribution Non-Commercial 4.0 International License (http://creativecommons.org/licenses/by-nc/4.0/), which permits non-commercial re-use, distribution, and reproduction in any medium, provided the original work is properly cited. For citation use the DOI. For commercial re-use, please contact editor@chitrolekha.com 
for research as regulated in Sanskritic lore (Basham 1971: 157, 171, 178), and the pains of hell enumerated in the Garuḍa Purāna ('Dharma-preta-kāṇ̣a', chap. 3) .

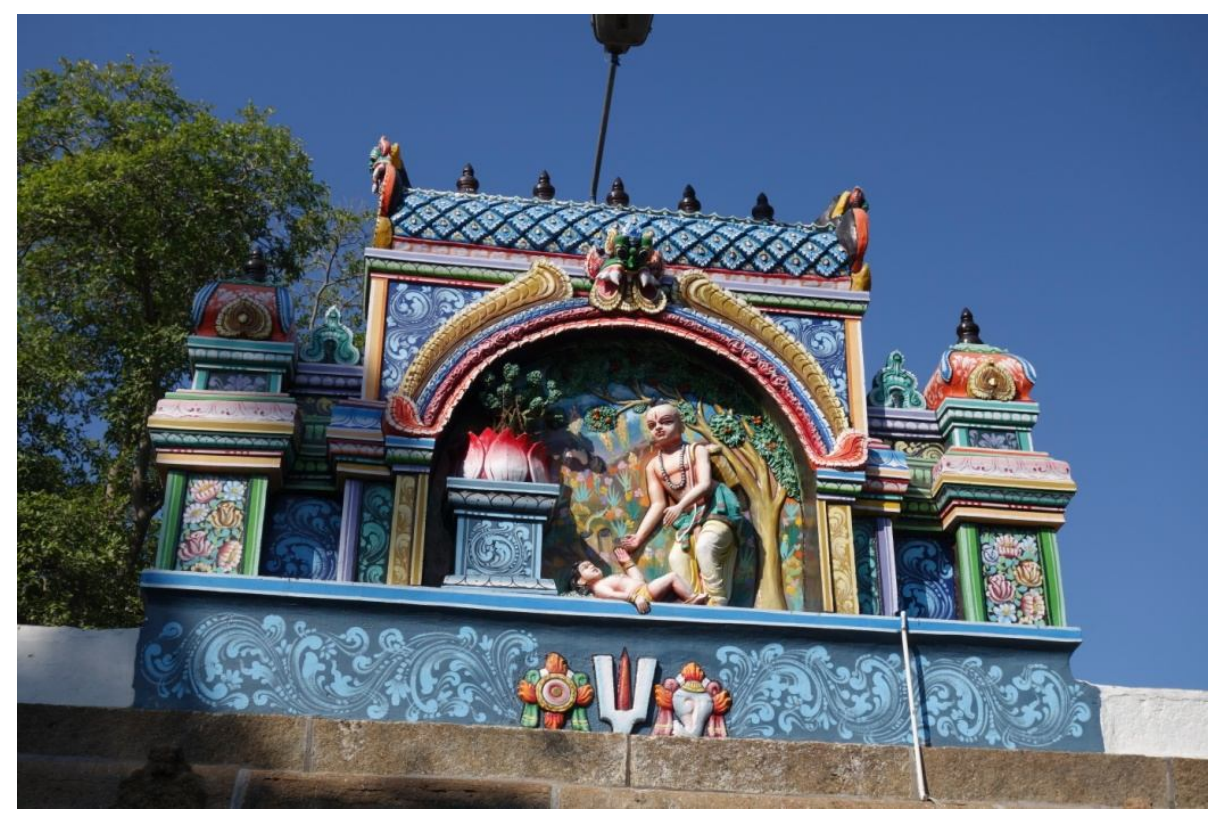

1. Peiyālvār finds Āṇțāl, Āṇtāạl-Vațapatraśāyī temple, Śrīilliputtūr $\odot$ Villiputtūr Temple \& R.K. Parthiban

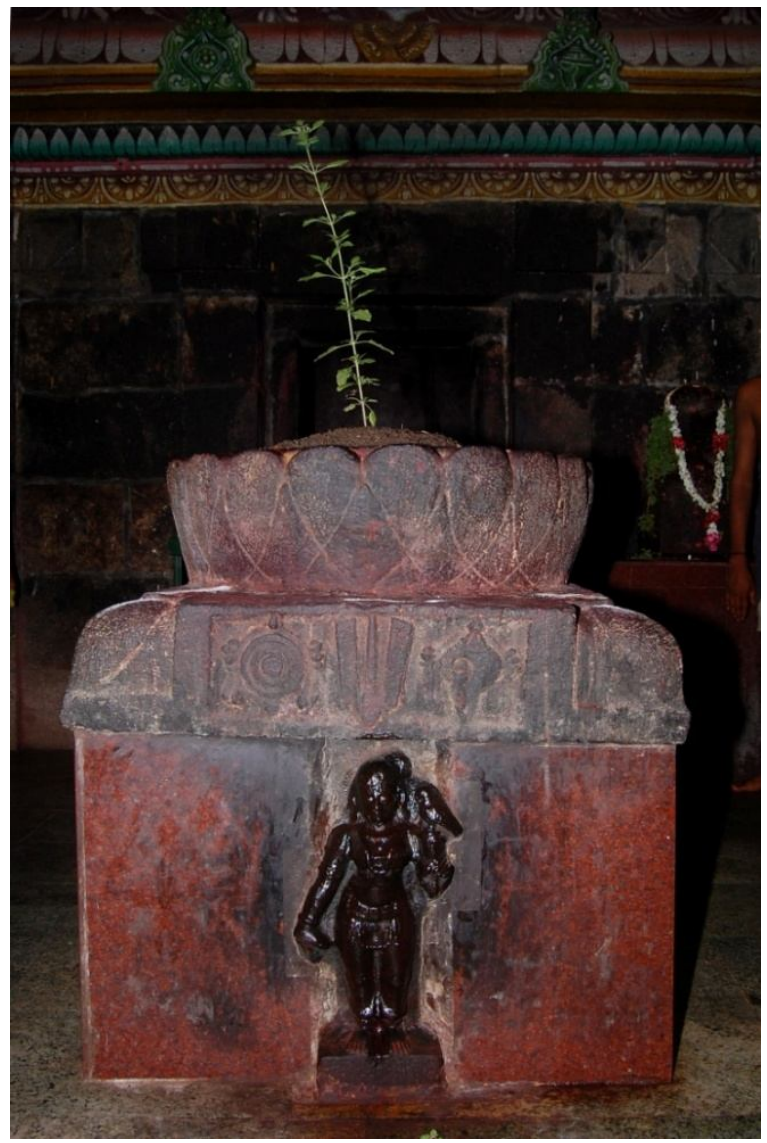

2. Āṇțāl, Balibera, Āṇțạl-Vațapatraśãyī Temple, Śrīvilliputtūr @ Villiputtūr Temple \& R.K. Parthiban 


\section{Method}

A word regarding the method for utilization of the Tamil hymns in the present essay may be added. The original text in any published work may not deviate from one another. Interpretations may differ as the hymns were analyzed by traditional scholars known as Ācāryas from the $11^{\text {th }}$ to the $19^{\text {th }}$ century $^{10}$. The text and translation followed for the present study is the commentary of Periyavāccān-pillại (c. 1167-1262 CE). For Roman transcription the Tamil Lexicon method is assiduously followed. Citations from the Tamil hymns are presented in Roman transcription (cf. Rajarajan, Parthiban \& Kalidos 2016 \& 2016a) with the nearest English translation that could better be a summary of the ideas. Certain societal practices in the $8^{\text {th }}-9^{\text {th }}$ century are beyond comprehension of dictionary meanings. The tirumoli under study in its tenth hymn adds: cettuppōvatōr pōtuninaintu ceyyuñceykai "the rites that are performed at a time when human beings are nearing death". The mystic's advice is to give up desires for mundane properties and pleasures, and "Praise the Lord" that offers everlasting bliss.

\section{Hymns on Death}

Ācaivāyc ceñra cintaiyarāki yannnַai yațțanַen puttiranַ pūmi

Vācavārkulalāl eñru mayan̉ki māḷum ellaik kạ̣ vāy tiravātē (Tirumoli 4.5.1)

At the time of death human beings are directed by passionate attachment and are under a neverending spell thinking of their mother, father, children, landed properties and wife and call out each one by their names. Death in this hymn is māl (mälutal "to die", to be finished TL V, 3181); PVP says "give up prāna (breath, respiration; Apte 2012: 375)".

Do not waste time at the verge of death. Think of Keśava, Puruṣottama and the Lord Varāhamurti and mutter the sacred names if to be redeemed.

Cīyin̄ār cirrantēriya puṇmēr cerrralērik kulampirunt en̉kum

İyināal arippuṇțu mayañki ellaivāyc ceñru cēr ... (Tirumoli 4.5.2)

The decaying body is swarmed by flies that lay eggs on mortal wounds, further worsened by oozing pus that leads the dying person to swoon and knock at the doors of death; it is the carama-käla, time of death (PVP) $)^{11}$.

Before you reach the end-point think of the Lord, utter the sacred aștākșara-mantra (i.e. Om NaMoNāRāYaNaYa), and fold the hands up above the head in reverence.

Cōrvin̄ār porul vaittatuṇțākir collu colleñru currrumiruntu

Ārvinaālum vāytiravātē yanta kāla mațai... (Tirumoli 4.5.3)

You had concealed all the riches underneath the earth, and forgot where these properties are ${ }^{12}$. Your kith pester you to tell where the hidden riches are? Your physical status is such even if your favourite youngest wife demands ${ }^{13}$; you are unable to open mouth at the antama-kälam (time of breathing the last).

Build a mānasa-mandira [ärvamennpatōr-kōyil for kuṃbhäbhișeka], consecrate the image of Mādhava [prathiștha] and offer flowers of love [prema-pușpāñjali] ${ }^{14}$ if you are to be redeemed from the clutches of the messengers of Yama ${ }^{15}$.

Mēl eluntatōr vāyun kiḷarntu mēñmițarrinnai yulḷlela vāñkik 
Kālun̉ kaiyum vitirvitirttērik kaṇnưrakka māvatan (Tirumoli 4.5.4)

At the time of death gas $\left[v \bar{y} y u^{16}\right]$ in your body moves upward and attacks the heart naturally resulting in hands and legs jerking to and fro in epileptic attack ${ }^{17}$.

The remedy is to inhale the pranava-mantra, i.e. 'Om' for three mättirai ${ }^{18}$ unit of time inside the heart and practice yoga meditating on Viṣnu, the Black'.

Mați vali vantu nīrppulan cōra vāyil ațtịa kañciyum minṇțē

Kațai vali vārak kaṇța mațaippak kạ̣ urakkam (Tirumoli 4.5.5)

Water pours in between the thighs through the penis ${ }^{20}$, and the gruel ${ }^{21}$ fed into the mouth automatically drops out and stops heart-beat, the grains of food peeping out at either end of the mouth leading to kaṇnurakkam (parama-nidrä "eternal sleep”).

If you have the will-power to win the battle against death keep the Lord that reclines on the Ocean of Milk in your mind ${ }^{22}$.

An̉kam viț̣tavai yaintum makarrri yāvi mūkkininir cotittu pinnnaic

Cańkam viț̣avar kaiyai marittup paiyavē talai cāy ... (Tirumoli 4.5.6)

The vital five-winds (pañca-prāṇa PVP, cf. the Gìtā 7.4 bhūmi “earth”, āpaḥ "water”, anala "fire”, vāyu "air", kham "ether") in the human body had subsided when the senior men nearby test the corpse by placing fingers on nose to declare "He is dead"23, and they pose the question "what to do next?"

If you keep Madhusūdana in mind, it is possible to avoid any catastrophe. The breath may not stop if surrendered at the feet of Viṣnu.

Tennnavan ramar ceppamillātavar cēvatakkuvār pōlap pukuntu

Pinnnum vanַkayirrrāā piṇit terrrip pin munnnākav ilu ... (Tirumoli 4.5.7)

The servants of Yama (repeated in Periyālvār-Tirumoli 4.10.2-4, 9) are merciless. When the life-span of an individual is over, they arrive with tight ropes (pāśa "noose") to bind the departed soul24 as bulls are tied by servants (niccayonin "low born" PVP) working in the cowshed; turn the dead person's face upside down to drag him to the naraka "hell".

If you think of Madhusūdana you shall be gifted to be commanders in the world of Viṣnu, the Vaikunțha.
Kūțikkūṭi yurrrārkal iruntu kurrra nirkka narrrañkal paraintu
Pātip pāṭiyōr pāțaiyilițțu narip pațakkoru pākuțam pōlē
Kōți mūti yețuppatan ... (Tirumoli 4.5.8)

The kith and kin of the departed person arrive in several groups to extol his fame (see note 1), keeping under check the misdemeanors committed by him, and cry aloud singing his glories ${ }^{25}$. They place the corpse in a stretcher ${ }^{26}$, offer new garment ${ }^{27}$ as though feeding a herd of jackals with pots of the juice of jiggery so that the journey to the crematorium or burial-ground begins (Dallapiccola 2010: fig. cat. 3.1).

You may skip over the world of Yama if you find time to sing and play with Govinda (see note 23) that is decorated with the kaustubha ${ }^{28}$.

Vāy oru pakkam vāñki valippa vārtta nīrk kulik kaṇkạ milarrạat 
Tā yoru pakkan tantaiyoru pakkan tāramoru pakka malattat

Ti yoru pakkañ cēr ... (Tirumoli 4.6.9)

Due to the epileptic attack, the mouth is deformed at either end, the words fail to appear and tears pour through eyes. Mother on one side, father on the other side and wife standing nearby; they are dejected and looking round. Before the corpse is mounted on the funeral-fire, think of the Lord.

You may escape from the punishments of the servants of Yama ${ }^{29}$ if you tightly catch hold of the redeyed Black, CeñkaṇMāl.

The tenth hymn says the man is on his death-bed; the mourning of which is retold by Viṣnusiddha of Villiputtūr, i.e. Śrivilliputtūr (Fig. 2). It seems the man on last-bed is round the age of sixty so that his mother, father, wife and children are gathered melancholically to see how he suffers. He had hidden his treasures in an underground vault, which worries the kith and look at him pathetically to say where the riches are hidden. The dying man is unable to speak. His mouth and legs are attacked by epilepsy inhaling the last life-wind, vāyu or präna. Another old man has come, places his fingers on the nose of the dying person and declares he is dead. The corpse is placed in a stretcher, taken to the crematorium and burnt. He is ultimately conveyed to heaven or hell determined by the good or evil done during lifetime. The mind is its own place and in itself can make a hell of heaven or heaven of hell (John Milton). Some say life is impermanent, and death brings the final solace and everlasting bliss in heaven.

The Ālvārs have recorded the notions of old age, disease and death ${ }^{30}$ that were turning point in the life of the Buddha (Arnold 1949: Book II) who renounced princely life and took to sannyāsa. A detailed description of the death process is new in case of the Tamil bhakti hymns as reported in Tirumoli 4.5. Naturally, the question is why Periyālvār presents such a minute description? It is not clear whether the Ālvār mourns the demise of his beloved daughter, Āṇțāl (Fig.3) at a young age viewing death in its broad context of the biography of a Vaiṣnava savant, the Bhăgavata. However, this could only be a vague gesture for which we have no definitive clues from the other hymns of either Periyālvār or Āṇtal ${ }^{31}$. Tirumoli 3.8.4 is important. To quote,

Oru makal tanַnai uṭaiyēn ulakam nirrainta pukalal

Tirumakal pōla valarttēn CeñkaṇMāl tān koṇtụ pōñān ...

"I have one daughter; I have brought up the maiden as Tirumakal/Śrīdevī to deserve the appreciation of the people of world. The red-eyed Black took her away..." Konțuponnann $\underline{n}^{32}$ is an important phrase that is subject to speculation. In folk parlance it denotes death. ${ }^{33}$ True Vaișnavas believe they breathe the last at the feet of Govinda (see note 23). Probably, Ānțāl died at a young age (cf. Keats dying of tuberculosis) that is camouflaged in the Guruparamparā mythologies as a wedding with Raniganātha; the maid merging with eternity. Darwinian historians will never accept this. It is important to note Āṇțāl had to face an honorable end because Periyālvār says her fame was universal, ulakam-níraintapukal; maybe she was the only woman mystic in Vaiṣnava lore. Nappinnnai and Rādhā are of a different genre; later came Mīrābāī (Santhana-Lakshmi-Parthiban 2015). Āṇṭāl came to be identified with Bhūdevī (cf. supra. Tirumakal, Ramanan 1989: 53) and was a cult icon installed in separate chapels in Tamilnāọu, a status that Mīrabāĩ and Rādha could not reach. Viṣnu in middle, Śrī to the right and Ānțāl to the left is the established architectural setting (e.g. Kūṭal Alakar at Maturai) in most Viṣnu temples of Tamilnadu since the Vijayanagara-Nāyaka period (Rajarajan 2006: II, plans II, $\mathrm{VI}, \mathrm{IX}, \mathrm{XI}, \mathrm{XIV})^{34}$. It is significant to observe the architectural design of the Śrivilliputtur temple and rituals accord a place of eminence to the Feminine Principle (Fig. 3); a subject matter that is investigated by R.K. Parthiban (cf. Parthiban and Rajarajan 2016: fig. 2). The efforts of Periyālvār are 
directed toward Māl-Viṣnu to assure protection for the craving soul in its relentless pursuit of righteous living: nī yennnaik käkka vēṇțum "Thy bounden duty is to protect me (from terrors)" (TM 4.10.3-9).

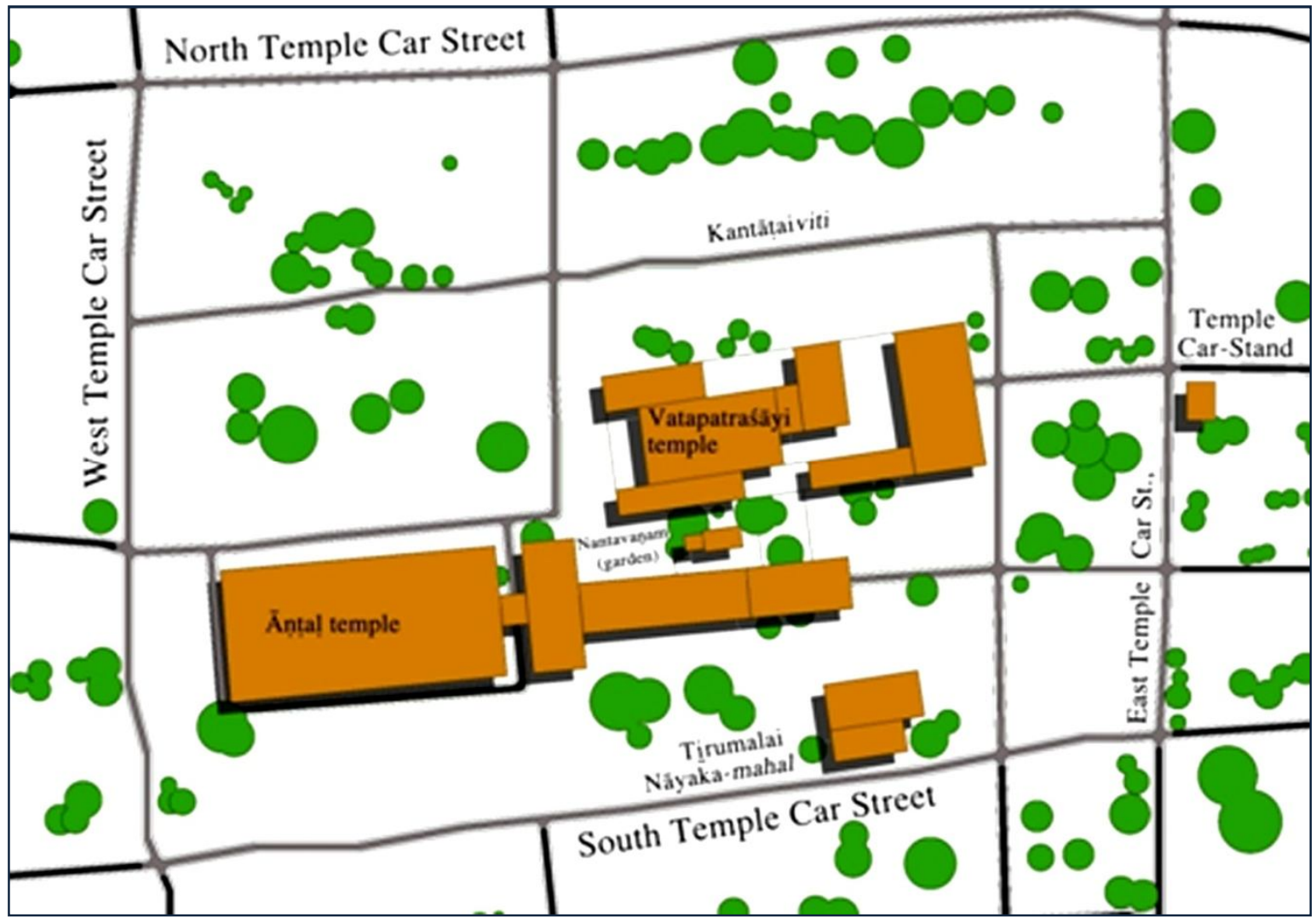

3. Plan of the Śrīvilliputtūr Temple (by Vijaya-Raghavan Vira-Visodhana)

Indomitable souls never die $^{35}$, e.g. the transformation of Kannaki from mortality to divinity (Rajarajan 2015: chap. V) ${ }^{36}$; they live long by virtue of the heritage (Indian dharma, Tamil aram) they had bequeathed for humanity; takkār takavilar enpatu avaravar eccattār känappațum "a fit person's legacy is estimated by what he had left" (cf. Pope's translation of Tirukkural 114). France had undergone disastrous experiences with the Bourbons after the death of Napoleon (cf. Hutchinson n.d.: pl. facing p. 1), his statue brought back to Paris that was acclaimed by the blind mother of Bonaparte "Once again the Emperor is in Paris" (Nehru 2004: 455). Cleopatra in Shakespeare is a formidable personality living long in the pages of history. Death cannot wither immortal souls.

Give me my robe, put on my crown; I have Immortal longings in me ('Antony and Cleopatra' V, ii)

Cleopatra and Octavius Caesar mourn the suicidal death of Antony that has gone deeply recorded in dramatic verses of Shakespeare in 'Antony and Cleopatra':

Cleopatra speaks: “... a Roman by a Roman / Valiantly vanquished... Noblest of men... O, wither'd is the garland of war, / The soldier's pole is fallen.../ we have no friend" (IV, xv) 
Octavius Caesar speaks: "A greater crack. The round world/ Should have shook lions into civil streets/ And citizens to their dens/ The death of Antony/ Is not a single doom; in the name lay/ A moiety of the world" $(\mathrm{V}, \mathrm{i})$

2 It is not known under what circumstances Ānțāl died. Her marriage with Rañganātha (Tamil Arañkañ) takes place in the Śriranigam temple (cf. Rajarajan, Parthiban and Kalidos 2017: 15-17). After this event she disappears from the pages of history, and is supposed to have merged with "eternity" (ĀrāyirappațiGuruparamparāprabhāvam, 49-50). How? The Guruparampara hagiographers do not seem to reply this question. Merging with the Lord is a fantastic hallucination (Cerikanmmältān koṇtupōnnann "the red-eyed Black-Viṣnu carried her away" Tirumoli of Periyālvār 3.8.4); Āṇțāl must have died due to some malady or other means hook or crook, volunteered or forced (cf. Tirunālaippōvār in Tiruttoṇtar Purānam). For further reading on premature death, cf. Blackburn 1985: 260-271.

3 Keats must have been of the age of Ānțāl just twenty-six while breathing the last. He had a premonition of death (see note 24); cf. "... life is but a day; / A fragile dew-drop on its perilous way" ('Sleep and Poetry', Selected Poems, p. 43).

4 Images illustrating the parinirvāna of the Buddha (Gadebush n.d.: 33; Ahuja 2013: fig. 6) are laid up in pretäsana (symbolic of breathing the last); a hand touching the earth, bhümisparśamudra (to symbolize the impermanence of worldly life). Is it particularly related to Bodh Gaya? (Ahuja 2013: 194).

5 For a recent on study on death, see Ahuja (2013: 14-49). Naman P. Ahuja has systematically made a chapter 'Death: The Body is but temporary', with thirty-nine illustrations covering a period over ancient to modern with an array of literary analysis.

6 Known as Pațtarpirān-Vittucittan (lord of bhatțas, Viṣnusiddha), he is the author of 473 hymns, mostly quatrains brought under the Tiruppalläntu and Tirumoli (cf. Rajarajan, Parthiban \& Kalidos 2016 \& 2016a). The names Pațtarpirān (cf. Kalidos 2015: 139) and Vițțicittan appear in the Tiruppāvai (30), Nācciyār Tirumoli (1.10, 5.11) and Tirumoli (3.1.11, 3.3.10).

7 For an analysis of the subject in Kulacēkara Ālvār's Perumäl Tirumolii, see Anandakichenin 2014: 167-201. It is interesting note the Islamic Marsiyahs tradition are poems of tribute and lament upon the death, in Iraq. This genre of poem narrates the whole series of experience encircling the qurbani-e "azim "great sacrifice" offered by Husain, the grandson of Prophet Muhammad (cf. Bard and Ritter 2009: 21-53).

8 It is not about mere understanding of the biography of the Tamil mystics, but the transformation of epitome of those mystics into literature and art. It is combination of two-fold theories, the mystics' real life and their re-embodiment in the folk imaginative narrations regarding death. It is pertinent to realize the factual course that links the folklore and the hagiography that pinpoints the mysticism of the Tamil mystics (cf. Prentiss 1999: 109).

9 Dated in C. 900 CE (O'Flaherty 1994: 18), the work is posterior to Periyālvār by about fifty years.

10 This phase covers the Ācāryas from Rāmānuja to Maṇavāla-māmuṇikal; the forerunner Nātamuñi is dated in the $9^{\text {th }}-10^{\text {th }}$ century (cf. Zvelebil 1974: 91), last in the line being Aṇnangarācārya.

11 Carama-tacai is the "moment of death" and carama-kiriyai "funeral rites" (TL III, 1314). Cf. śramana is a Jain trained in sallekhanā "ritual-death" (Settar 1986: 271, 273).

12 Misers earning wealth by illegal transactions such as money-lending is common in any part of the world; e.g. Shylock in Shakespeare's 'Merchant of Venice'. Such people in those times buried "black-money" in secret vaults never to see the light again. News reports of the discovery of hidden treasures are quite common in the vernacular dailies in South India.

13 With rich men, aristocrats and nobles' polygamy was common. This was a living tradition some fifty years ago. I am told my grandfather and great-grandfather had more than one wife and several concubines; e.g. Mātavi, the dancing girl in Cilappatikāram. 
14 These cult practices are retold in the Cilappatikäram (28.224-233); i) expert architects, nūneri-mäkkal erecting a Temple for the Goddess of Chastity, Kannaki, ii) installation of an image by those proficient in prathiștha ceremony and iii) offering pușpāñjali, pūppali (cf. Rajarajan 2016: chap. V).

15 Yama-dūtas ('Yamapațārar' PVP) are called 'Aravar'. They inflicted punishments such as taking away life with a noose. Pāśa is tanțam/daṇda; therefore, Yama is daṇdanāyaka "rod-applier", a judge (MonierWilliams 2005: 466).

16 Vāyu (wind or gas), pittam (bile) and kapam (phlegm) are supposed to be present at a balanced ratio in the human body. If any one goes up or subsides abnormally that results in ailments and death (cf. UttaraRāmāyaṇam cited in TL II, 722).

17 Contemporary medical technology says this is "high temperature" or "heart-attack" resulting in paralysis leading to death.

18 Māttirai is a unit of time, the fracture (2/5) of a second (TL V, 3153).

19 Scholars have discussed the impact of hathayoga in the iconography of Indian images of the gods and goddesses (Goldberg 2002: chap. 2).

20 This is called amuri, also known as civa-nirr (Śiva's water) or virra-maruntu (medicine of chivalry) in the Tirumantiram (3.20.1-6) that is considered either urine or semen. The Tamil siddhas had a belief in urinetherapy.

${ }^{21}$ Kañci is the breakfast; lunch and dinner for the proletariat in the Maturai region among the piramalaikkallans (cf. Dumont 1986: field work in 1920s). These people are today MLAs, MPs and million-dollar ministers. Once kañci-eaters, they are today dining in five-star hotels. "Power corrupts and absolute power corrupts absolutely." This subject is worth investigating keeping in reserve Dumont's work.

22 This hymn goes on to add when the messengers of Yama drag the victims' dogs of infernal regions bite thighs, strike the sinners with lances and they are deprived of garments on the way. To an Indian, it appears the penal tortures of the Garuda Purana are portrayed in the High Renaissance paintings of the Vatican (Gallico 1999: figs. pp. 98, 100-101, cf. 54-55), which means religions of the world share some common thoughts concerning natural or human disasters.

23 Tribal and folk population today has their own country doctors to test the status of dying persons. Fingers are placed on nostrils to find out whether he breathes or not and decide the future course of action.

24 See images of Kālāri in Indian art through the ages; when Yama attempts to cast the noose on Mārkandeya, Śiva kicks the Lord of Death to protect the devotee (Rajarajan 2006: II, pls. 83-84; Kalidos 2006: II, pl. XVIII.2; Ahuja 2013: 31-32, fig. 12). The images illustrated in Kalidos, Rajarajan and Ahuja range from the $8^{\text {th }}$ to the $17^{\text {th }}$ century.

25 Particularly women sing a death-song, called oppäri in Tamil that recollects the greatness of the dead person (Nabokov 2000: 155). On this occasion evil deeds are forgotten and the person's noble qualities are remembered (see note 1); cf. Mark Antony in 'Julius Caesar' (I, ii; III, ii). While singing, these women beat their chest with hands known as märațittal (chest beating). Now-a-days such professional singers do the job paid for their labour.

26 The stretcher called pätai is new of bamboo poles and coco leaves and decorated with flowers. At the graveyard it is broken and discarded. While lifting the corpse to mount on the stretcher, they shout "Govindā, Govindā"; Tirumoli 4.6.5 adds if the name "Govindā-Govindā" is muttered the evils of hell never haunt a devotee. When the procession moves dancing and merry-making by drinking arrack is very popular; particularly among the down-trodden communities.

27 The new garments are known as kōțī (means the last or end of the garment). Ānțāl talks of the kōți (Näcciyär Tirumoli 6.3) offered at the time of her wedding. The garment offered at the time of death is kōti (also known as cittēvi-cēlai, sari of Śrīdevī for women) by the nearest kin (e.g. uterine sister or brother). 
Ānțāl talking of [mantirak]-kōti "blessed garment" is enigmatic. Is it a premonition of her nearing end? I am told the new garment offered at the time of marriage is called kūrai (cf. Näcciyär Tirumoli 3.2, 4, 8-9; Tirumoli of Periyālvār 4.6.1-2) which is tucked to the braid at the time of tying täli (marriage badge in gold) and nuptial ceremony.

28 Kaustubha, Tamil kauttuvam is a celebrated ratna (jewel) of Viṣnu-Kṛ̣ṇa that was obtained from churning the Ocean of Milk (Liebert 1986: 132).

29 Arava-tantam is the cruel punishment meted out to inhabitants of the hell by servants of Yama. Tantam is daṇda (see note 12). Tirumoli (4.6.1-9) declares if the names of Vișnu are uttered the evils of naraka[m] do not afflict a devotee.

30 See Tiruvāymoli 2.3.10: pirappup-pini-mūppu-pirapparru "birth, disease, old age and give up birth, i.e. death".

31 The Guruparamparā mythologies could not be taken into serious account because they are later medieval fabrications.

32 Konțukitțupōka (taking away), tūkkikițtupōka (lift the stretcher and go) and cettuppō ("go and die" Tirumoli 4.5.10) are imprecatory phrases current in folk circle to denote "death".

33 See Blackburn (1985: 255-274) for analysis of death concepts in folk and classical Hinduism. The work clearly demarcates the deviation of death between the classical and folk Hinduism. Death metaphors in folk and classical have similarities, continuity and differences, but folk is divergent also coherent to understanding. One interesting factor in folk worship is the oral performance for the deified dead, as they trace the indigenous mode of Hinduism. Further these folk factors are fundamentally courageous; simple and earthly, non-celestial, the characters are human, and finally the theme is human struggle between love and death. The Tamil literary sources carry ample evidences for the female struggle and their deification, good examples are Kaṇnaki (Rajarajan 2000: 401-14, Lefévre 2011: 86-87), Kāraikkālammaiyār (Pechilis 2008: 24) and Āṇțāl (Rajarajan 2017: 55-56). In folk cult, the male characters are deified just for their heroic deeds, while female characters undergo differential ordeals of audacity, gallantry, and exoticism. The feminine folk is equally powerful and sometimes extremely violent.

34 R.K. Parthiban (Research Scholar in Design Department, IIT, Hyderabad) is working on the architecture visà-vis woman intangible heritage with focus on the Śrivilliputtūr temple. He is a student of (Brandenburg Technical University, Cottbus) of World Heritage Studies, UNESCO sponsored. His search is to locate the "woman-power" in the architectural history of intangible heritage in the Indian context. The photographs added to the present article go to his credit, shot in 2015 during Märkali Festival.

35 The Bhagavat Gitā, scripture of the Hindus includes sermons on death. A brief note may be added here citing the original.

Antakāle ca māmeva smaranmuktvā kalevaram| yaḥ prayāti sa madbhāvaṃ yāti nāstyatra saṃśayaḥ|| (Gītā 8.5).

"When one breaths his last thinking of Me, he reaches Me. He acquires my form."

Yaṃ yaṃ vāpi smaranbhāvaṃ tyajatyante kalevaram| taṃ tamevaiti Kaunteya sadā tadbhāvabhāvitaḥ|| (Gïtā 8.6).

"Whichever one thinks of that which is dear to him at the 'end-time' (Tamil kațaici-kälam) and melts his body (cf. nīrāy urikki 'Civapurāṇam' l. 69 of Mānikkavācakar's Tiruvācakam see Pope 2003: 6) he reaches the desired end."*

* Āṇtāl was all the time thinking of the Lord of Ārańkam/Śrïrangam, and so the myths say she reached the Lord ultimately. 
Kaviṃ purāṇamanuśāsitāra maṇoraṇīyāmsamanusmaredhyaḥ| sarvasya dhātāramcintyarūpa mādityavarṇạ̣ tamasaḥ parastāt|| Prayāṇakāle manasā'calena bhaktyā yukto yogabalena caiva| bhṛvoṛmadhye prāṇamāveśya samyak sa taṃ paraṃ purușamupaiti divyam|| (Gïtā 8.9-10).

"If you think with devotion the all-knowing, the antediluvian, the all governing, the minutest particle of atom, the bearer of all; he is for not cognizable, shining as sun, beyond darkness at the time of death with determination keeping the Lord in between your eye-brows, you (ätma "self") certainly reaches the Parama-Purușa (Eternal Self)."

The Gitā says death is end of the existing body. The soul, ātma never dies (Gitā 2.18, 20). It migrates to another body according to the karma done in previous birth. The divyātma of sages and seers (differently known as muni, rși, yogi, siddha and so on) ultimately merges with Eternity that differs from religion to religion, Brahman in case of the Hindus; the Holy One, Jehovah, Yahweh, Ahura Mazda, Zeus and so on.

36 Kannaki's end is also mysterious. She appears on the hill west of Maturai and is transported to the other world in an aerial chariot. A temple was built for her and a cult image consecrated; then she appears on the sky as a lightening figure and says (Rajarajan 2016: chap. V):

VeñVēlān kuñịil viḷaiyāțtu yāñakalēn (Cilappatikāram 29, v. 13)

"I shall continue to play on the hill of Vēlan/Murukan, and never depart from here".

Ardent Vaiṣnavas dogmatically believe Anțāl is proverbially living in the Śrīvilliputtūr temple. R.K. Parthiban has spotted a living patțar/bhațta that is considered a descendant of Periyālvār (Parthiban \& Rajarajan 2016: fig. 21). The utsavabera of Ānțāl is taken out for procession from his house during the Mārkali (December-January) Festival. Thanks to R.K. Parthiban for the information.

\section{References}

Anandakichenin, Suganya (2012) “Kulacēkara Ālvār’s ‘The Lament of Daśaratha”, Journal of Vaishnava Studies, Vol. 22.2: 167-201.

Antony and Cleopatra, In 'Shakespeare Complete Works'.

Apte, V.S. (2012) The Student's Sanskrit-English Dictionary, $1^{\text {st }}$ ed. (Poona, 1890) reprint Delhi: Motilal Banarsidass.

Ārāyirappați-Guruparamparāprabhāvam, ed. S. Krishnaswamy Aiyangar, Family Trust (editor's), Tiruchi: Puttūr.

Ariswara (2008) Borobudur and Temples of Java, Magelang: Indonesia.

Arnold, Sir Edwin (1949) The Light of Asia, Bombay/Calcutta: Jaico.

Bard, Amy and Valerie Ritter (2009) "A House Overturned: A Classical Urdu Lament in Braj Bhasha", In Kelly Pemberton and Michael Nijhawan eds. Shared Idioms, Sacred Symbols, and the Articulation of Identities in South Asia, New York \& London: Routledge.

Basham, A.L. (1971) The Wonder that was India, Calcutta: Rupa.

Blackburn, Stuart H. (1985) “Death and Deification: Folk Cults in Hinduism”, History of Religions, Vol. 24.3: 255274.

Cilappatikāram, (2008/2011) ed. Na.Mu. Vēñkațacāmi Nāțțar, Chennai: Rāmayya Patippakam.

'Civapurāṇam', see Tiruvācakam.

Dallapiccola, A.L. (2010) South Indian Paintings A Catalogue of the British Museum Collection, Ahmadabad: Mapin. 
Dumont, Louis (1986) A South Indian Subcaste. Social Organization and Religion of the Pirmalai Kallangs, (reprint) Delhi: Oxford University Press.

Gadebush, Raffael Dedo et al. (n.d.) Museum of Indian Art Berlin. Munich, London, New York: Prestel.

Gallico, Sonia (1999) Vatican. Roma: Edizioni Musei Vaticani - Arts Italia Editrice.

Garuḍa Purāna, (1986) Part II, Board of Editors, Delhi: Motilal Banarsidass.

'Genesis', In The Holy Bible [Old and New Testaments], (n.d.) London: Trinitarian Bible Society.

Gītā: Bhagavat-Gïtā 1. Svāmi Citbhavānanda transl. Sri Rāmakrishṇa Mațha: Tirupparāytturini 1977; 2. Gita Press: Gorakhpur 1984/1996.

Goldberg, Ellen (2002) The Lord who is Half Woman Ardhanäriśvara in Indian and Feminist Perspectives. $1^{\text {st }}$ ed., Albany: State University of New York.

Gustave, Le-Bon (1974) The World of Ancient India. (transl. David Macrae), New York: Tudor.

Hutchinson, (n.d.) History of the Nations, I. London.

Julius Caesar, In 'Shakespeare Complete Works'.

Kalidos, Raju (2006) Encyclopaedia of Hindu Iconography: Early Medieval, II Śiva. Delhi: Sharada.

----. (2015) “Bhatkal or Bhațkal: Some Thoughts for Consideration", In J. Soundararajan, Glimpses of Vijayanagara-Nāyaka Art, Delhi: Sharada. 135-60.

Keats, John (1996) Selected Poems. et alii., reprint London: Penguin.

Lefévre, Vincent (2011) Portraiture in Early India Between Transience and Eternity, Leiden \& Boston: Brill.

Liebert, Gösta (1986) Iconographic Dictionary of the Indian Religions Hinduism-Buddhism-Jainism. $1^{\text {st }}$ ed., Delhi: Sri Satguru.

Monier Monier-Williams, (2005) A Sanskrit-English Dictionary. [1 ${ }^{\text {st }}$ ed., 1899], reprint Delhi: Sharada.

Nabokov, Isabelle (2000) "Deadly Power: A Funeral to Counter Sorcery in South India", American Ethnologist, Vol. 27.1: 147-168.

Nācciyār Tirumoli of Āṇțāl, In ‘Nālāyiram’.

'Nālāyiram': Nālāyirativviyappirapantam (2010/2014) ed. Pulavar Ta. Tiruvēńkața Rāmāñucatācañ, 4 vols., Chennai: Umā.

Naman P. Ahuja, (2013) The Body in Indian Art and Thought. Brussels, Ludion, Antwerp: Europalia International.

Nehru, Jawaharlal (2004) Glimpses of World History. New Delhi: Penguin.

O'Flaherty, Wendy D. (1994) Hindu Myths A Sourcebook translated from the Sanskrit. New Delhi: Penguin.

Parimoo, Ratan et al. (1991) The Art of Ajanta: New Perspectives. $1^{\text {st }}$ ed., New Delhi: Books \& Books.

Paripātal, ed. Pō.Vē. Cōmavcuntarañār, $1^{\text {st }}$ ed. [1957] Chennai: Kalakam.

Parthiban, R.K. \& R.K.K. Rajarajan 2016. "Nāyaka chefs-d'oeuvre: Structure and Iconography of the Śrīvilliputtūr Tër”, Acta Orientalia, 77, 145-91.

Pope. G.U (1900/2003). Tiruvācakam (text and translation). University of Madras: Chennai.

Prentiss, Karen Pechilis (1999) The Embodiment of Bhakti. New York and Oxford: Oxford University Press.

PVP: Periyavāccān-piḷ̣ai, Commentary on the ‘Nālāyiram' other than the Tiruvāymoli: maran'sdog@org.

Ramanan, Mohan (1989) "Āndāl's "Tiruppāvai", Journal of South Asian Literature, Vol. 24 (1989), no. 2, pp. 5164. 
Rajarajan, R.K.K. (2000) Dance of Ardhanārī as Pattinī-Kannnaki: With special reference to the Cilappatikäram. Berliner Indologische Studien, Vol. 13/14: 401-14.

----. (2006) Art of the Vijayanagara-Nāyakas: Architecture \& Iconography, 2 vols. New Delhi: Sharada.

----. (2016) Masterpieces of Indian Literature and Art - Tears of Kannaki: Annals and Iconology of the 'Cilappatikäram'. New Delhi: Sharada.

Rajarajan, R.K.K., R.K. Parthiban and Raju Kalidos [Principal Investigator] (2016) Hymns for Cosmic Harmony 'Nāläyirativviyappirapantam' Four-Thousand Divine Revelations (Roman Transcription, English Summary and Transcendence), 4 vols. (MS circa 2,300 pages), New Delhi: Jawaharlal Nehru University.

Rajarajan, R.K.K., R.K. Parthiban and R. Kalidos [Principal Investigator] (2016a) Concise Dictionary of Vișnuism based on 'Näläyirativviyappirapantam' (MS circa 2,200 pages), New Delhi: Jawaharlal Nehru University.

Rajarajan, R.K.K., R.K. Parthiban \& Raju Kalidos (2017) Samāpti-Suprabhätam - Reflections on South Indian Bhakti Tradition in Literature and Art. New Delhi: Sharada.

Santhana-Lakshmi Parthiban (2015) "Nappinnnai, Rādhā and Mirābāĩ in the Historical Vortex”, Paper presented in the National Seminar on 'Classical Tamil', Gandhigram Rural University, Gandhigram.

Settar, S. (1986) Inviting Death, Historical Experiments on Sepulchral Hill, Dharwad: Institute of Art History.

----. (1990) Pursuing Death, Philosophy and Termination of Voluntary Termination of Life.: Dharwad: Institute of Art History.

Shah, Julia (2011). "Monasteries, Monasticism, and Patronage in Ancient India: Mawāsa, a Recently Documented Hilltop Buddhist Complex in the Sanchi Region of Madhya Pradesh", South Asian Studies, 27.2: 111-30.

Shakespeare Complete Works, (1964) Peter Alexander (Ed.), London \& Glasgow: ELBS.

Stewart, Desmond (1980) Mecca. [photographs by Mohamed Amin] New York: Newsweek.

Tirukkural, (2005) G.U. Pope (Transl.), Umānūl: Thanjavur.

Tirumantiram (n.d.*) vols. 14-16, under 'Panniru-Tirumuraikal’ (totally 24 volumes), Chennai: Vartamānañ Patippakam, (* released in 2015).

Tirumoli of Periyālvār, In ‘Nālāyiram’.

Tiruppāvai of Āṇțāl, In ‘Nālāyiram'.

Tiruttonțtarpurāṇam [Tirunālaippōvār] (2007) In Ca. Vē. Cuppiramaṇian, 'Pannnirutirumurai', 1125-1134. Chennai: Maṇivācakar Patippakam.

Tiruvācakam, see Pope (2003); Kallakam ed. Chennai (1948).

Tiruvāymoli of Nammālvār, In ‘Nālāyiram'.

TL: Tamil Lexicon, (1982 reprint) 7 vols. University of Madras: Madras.

Verardi, Giovanni (2012) "The Brāhmaṇisation of Gandhāra and Greater Gandhāra”, In Tiziana Lorenzetti \& Fabio Scialpi eds. Glimpses of Indian History and Art Reflections on the Past, Perspectives for the Future, Rome: Sapienza University of Rome. 153-72.

Yiengpruksawan, Mini Hall (2007) “The Interstitial Buddha: Picturing the Death of Śákyamuni”, Yale University Art Gallery Bulletin, 44-63.

Zvelebil, Kamil V. (1974) Tamil Literature. Otto Harrassowitz: Wiesbaden. 
29 | Deathbed, Breathing the Last, and Funeral Procession: Musing under the canopy of history

\begin{abstract}
About the Author
R.K.K. Rajarajan, Assistant Professor in Fine Arts at the Gandhigram Rural University, Gandhigram, Tamil Nadu. He has worked as Associate Professor in Visual Studies at the School of Arts and Aesthetics, Jawaharlal Nehru University, New Delhi and in the Eritrean Institute of Technology, Asmara. He was an Alexander von Humboldt Post-doctoral Fellow, in the Institut für Indische Philologie und Kunstgeschichte, Freie Universität, Berlin, Germany. He is a prolific contributor to international journals and published works from Netherlands, ClujNapoca, Rome, Naples, Berlin, Reinbeck, Oxford \& IBH, Routledge and several more in India (International: 27 \& National 39). His works on Masterpieces of Indian Literature and Art - Tears of Kannaki: Annals and Iconology of the 'Cilappatikäram' (2016), Rock-cut Model Shrines in Early Medieval Indian Art(2012), Art of the Vijayanagara Nāyakas: Architecture and Iconography 2 vols. (2006), and Minākși-Sundareśvara: Tiruvilaiyātạ Purānam in Letters, Design and Art (2013) in collaboration are norm-setting.
\end{abstract}

